\title{
Hepatitis B Virus Infection: Knowledge and Awareness Among the Patients Admitted in a Tertiary Care Hospital in Bangladesh
}

\author{
Hepatit B Virüsü Enfeksiyonu: Bangladeș'te Üçüncü Basamak Hastanesine Bașvuran \\ Hastalarda Bilgi ve Farkındalık
} \author{
(D) Muhammed Abu Azhar5 \\ 1Sylhet M.A.G. Osmani Medical College and Hospital, Clinic of Medicine, Sylhet, Bangladesh \\ 2Sir Salimullah Medical College and Mitford Hospital, Clinic of Medicine, Dhaka, Bangladesh \\ ${ }^{3}$ Dhaka National Medical College and Hospital, Clinic of Medicine, Dhaka, Bangladesh \\ 4 United Hospital, Clinic of Nephrology, Dhaka, Bangladesh \\ ${ }_{5}^{5}$ Green Life Medical College and Hospital, Clinic of Medicine, Dhaka, Bangladesh
}

(1) Nahida Zafrin1, (1) M.A. Sattar Sarkar2, (1) Md. Motlabur Rahman³, (1) Umma Salma3, (1) Tania Mahbub4,

\begin{abstract}
Objectives: Hepatitis B virus (HBV) infection is a major cause of morbidity and mortality in Bangladesh. An adequate level of knowledge and awareness among the general population is essential in prevention and control of the infection.

Materials and Methods: A cross-sectional case-control study was conducted among patients who were admitted to our hospital. Data was collected using a self-administered structured questionnaire and analyzed by using SPSS.

Results: Out of 240 respondents included in this study, 120 were hepatitis B surface antigen (HBsAg)-positive and 120, HBsAg-negative. The study shows that as compared to HBsAg-negative counterparts, HBsAg positivity rate was found to be higher in illiterate patients and among farmers, retailers, and day-laborer groups. A significant fraction did not have any knowledge about consequences of hepatitis B infection. More than two-thirds of the patients from both groups were unaware of transmission mode and vaccination of hepatitis B. About one-third (30\%) of the respondents mixed up hepatitis A with hepatitis B.

Conclusion: The majority of the patients included in this study had an idea about the cause of HBV infection. However, they had substantial misunderstandings about its mode of transmission and consequences. Hence, a specifically-targeted plan has to be formulated and implemented to increase the awareness about hepatitis B.

Keywords: Knowledge, awareness, admitted patients, hospital, Bangladesh
\end{abstract}

ÖZ

Amaç: Hepatit B virüsü (HBV), Bangladeş'te morbidite ve mortalitenin önemli nedenlerinden biridir. Genel populasyonda yeterli düzeyde bilgi ve farkındalık, bu enfeksiyonun önlenmesinde ve kontrolünde şarttır. Gereç ve Yöntemler: Başvuran hastalar arasında kesitsel bir olgu kontrol çalışması yürütüldü. Veriler, kendi kendine yönetilen yapılandııımış bir anket kullanılarak toplandı ve SPSS kullanılarak analiz edildi.

Bulgular: Bu çalışmaya katılan 240 hastanın 120'si hepatit B yüzey antijeni (HBsAg)-pozitif iken, diğer 120'si negatif idi. Çalışma, HBsAg'nin negatif olduğu meslektaşlarıyla kıyaslandığında, okuma yazma bilmeyen hastalar ile çiftçi, perakendeci ve gündelik iş̧̧i grupları arasında HBsAg pozitifliğinin daha yüksek olduğunu göstermiştir. Anlamlı bir kısmın, hepatit B enfeksiyonunun sonuçları hakkında hiçbir bilgisi yoktu. Her iki gruptaki hastaların üçte ikisinden fazlası, bulaşma şeklinden ve hepatit B aşılarından habersizdi. Katıımcıarın yaklaşık üçte biri (\%30) hepatit A'yı hepatit B ile karıştırmıştır.

Sonuç: Çalışmaya dahil edilen hastaların çoğu HBV enfeksiyonunun nedeni hakkında fikir sahibi idi. Bununla birlikte, bulaşma şekli ve sonuçları hakkında ciddi yanlış anlamaları mevcuttu. Dolayısıyla, hepatit B hakkındaki farkındalığı artırmak için spesifik olarak hedeflenen plan formüle edilmeli ve uygulanmalıdır.

Anahtar Kelimeler: Bilgi, farkındalık, kabul edilen hastalar, hastane, Bangladeş

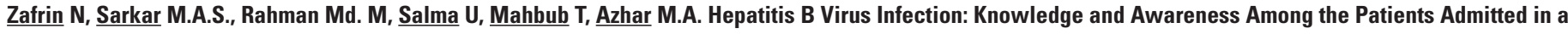
Tertiary Care Hospital in Bangladesh. 2019;25:6-13. 


\section{Introduction}

Hepatitis B, a significant global public health issue, can lead to progressive liver damage and liver cancer over time. Globally, more than 240 million people are exposed to chronic liver infections, of whom a million people die each year because of the acute or chronic consequences of hepatitis $B(1,2)$. Besides, nearly one-third of the world population has been suffering from hepatitis $B$ virus (HBV) infection, whereas 350 million of them are infected with chronic hepatitis $B$ characterized by the presence of HBV surface antigen (HBsAg) $(3,4)$.

In Bangladesh, the prevalence rate of HBV infection varies from $2.3 \%$ to $9.7 \%$ with carriers of 10 million approximately $(5,6)$. $\mathrm{HBV}$ is acquired either through vertical transmission, from mother to child, or through horizontal transmission from infected children $(7,8)$, unsafe use of therapeutic injections (9), blood transfusion, and unsafe sexual practices (10). However, because of low $\mathrm{HBeAg}$ positivity rate $(30.1 \%$ ) among pregnant females with HBV infection, perinatal or vertical transmission of $\mathrm{HBV}$ in Bangladesh is infrequent.

The rate of HBV carriers vary widely among the high-risk population of Bangladesh such as professional blood donors: 19.0 to $29.0 \%$, family members of HBsAg carriers: $20.6 \%$, healthcare workers: $8.7 \%$, parenteral drug abusers: $6.2 \%$ to $12.0 \%$, truck drivers: $5.9 \%$, sex workers: $9.7 \%$, and multiple units of blood recipients: $13.8 \%$ (11). Besides, HBV infection-a primary reason for liver disease in Bangladesh is responsible from 19.0\% to $35.0 \%$ of acute viral hepatitis, $35.7 \%$ of acute liver failure, $33.3 \%$ to $40.5 \%$ of chronic hepatitis and $46.8 \%$ of hepatocellular carcinoma (12).

Bangladesh being a developing country has less satisfactory health indicators (ranks $142^{\text {nd }}$ of 187 countries on human development index of the United Nations). Over one-third of the total population are living below the poverty line and have a fragile health structure; many patients cannot manage to pay for costly treatment of the diseases caused by HBV infection. Hence prevention is the only safeguard against the epidemic of viral hepatitis. Knowing facts and having proper awareness is critical to prevent the spread of these infections. In Bangladesh, some efforts have been made to assess knowledge and status of hepatitis $B$ vaccination (13) and seroprevalence of hepatitis virus antibodies (14) among newly admitted medical students, the molecular characterization of hepatitis B and C virus infections (15) among the admitted patients, risk factors related to HBsAg reactivity among outdoor patients (16), and knowledge and awareness among the infected male jobseekers to Malaysia (17). However, so far, no study focusing on the knowledge and awareness about hepatitis B transmission and its consequences among both HBVinfected and non-infected patients attending tertiary care hospitals in Bangladesh has been reported. This study is, therefore, designed to assess the level of knowledge and awareness regarding the mode of transmission, consequences, and prevention of HBV infections among patients of different categories admitted to the hospital. Hopefully, the outcomes of this study will render some baseline information necessary for the development of education and communication activities for prevention and management of hepatitis $B$ infection.

\section{Materials and Methods}

\section{Methodology}

\section{Study Design and Settings}

A cross-sectional case-control study was conducted from July 2016 to June 2017 on patients who attended Sir Salimullah Medical College and Mitford Hospital, Clinic of Medicine Inpatient, Dhaka, Bangladesh. The participation in this study was on a voluntary basis. Respondents were selected randomly and were included only after obtaining verbal informed consent. Admitted patients aged 18 years and above who recovered enough to provide a valid response to the questionnaire were included in the study. Respondents with a confirmed diagnosis of HBsAg-positive and no hepatitis B infection were considered as case and control, respectively. It is worth mentioning that data were collected from the patients selected on the first day of their admission. Admitted patients who were affected by other than hepatitis B e.g., chronic obstructive pulmonary disease bronchial asthma, peptic ulcer disease gastroenteritis, cholelithiasis, pancreatitis, poisoning, tuberculosis, urinary tract infection, acute kidney injury, chronic kidney disease, diabetes mellitus with various complications, drug reactions, malignancy, enteric fever, dengue, systemic lupus erythematosus, osteoarthritis, etc. were considered as control. A total of 240 admitted patients were taken as the sample size for this study. This study has been approved by an ethical review committee of the Sir Salimullah Medical College and Mitford Hospital, Dhaka, Bangladesh (approval number: ECMD/2016/17).

\section{Statistical Analysis}

A self-administered structured questionnaire was used to evaluate knowledge and awareness about the mode of transmission, consequences of and prevention of hepatitis B infection among patients who were admitted to the aforestated hospital. In addition to the demographic data (age, sex, religion, occupation, marital status, educational qualification, monthly income, and residence), 19 questions explored knowledge of hepatitis $B$ and its mode of transmission, 6 questions focused on knowledge about its consequences, 6 questions addressed knowledge on prevention of hepatitis B and 7 questions assessed participants' awareness of HBV infection. The questionnaires were delivered in english and bangla. The survey was conducted in different sessions. The patients were provided with the questionnaire, and a brief explanation was rendered to help them in completing it. Moreover, illiterate patients were interviewed face-to-face with understandable language. Face, content and convergent validity of the questionnaire was executed by expert faculty members of the Sir Salimullah Medical College and Mitford Hospital, Clinic of Inpatient. For reliability, a pilot test with 15 respondents was conducted using the preliminary questionnaire, and internal consistency (Cronbach's coefficient, $\alpha=0.77$ ) was found to be in acceptable ranges (18). After data collection, demographic characteristics of the respondents were analyzed using descriptive statistics. Answers to knowledge items with response options of yes, no, and not sure/don't know were divided into yes versus other if the right answer was yes (e.g., sexual intercourse can spread hepatitis B), and no versus other if the right answer was no (e.g., hepatitis B can be spread through coughing). A composite 
knowledge score was also created by summing the number of correct answers to the items addressing hepatitis B transmission. While responding to a Likert questionnaire item, respondents stipulated their level of agreement to a statement. SPSS 17.0 was utilized to analyze and process the data. The test statistics used for data analysis were student's t-test and chi-square test. A p value of $\leq 0.05$ was considered statistically significant.

\section{Results}

\section{Demographic Characteristics}

A total of 240 respondents were included in this study. Among them, 120 were HBsAg-positive (case group) and the other 120 were HBsAg-negative (control group). Table 1 demonstrates the demographic profile of the respondents. From the table, it is evident that the number of patients from the most common age groups, i.e., 31-40 years, $41-50$ years, and more than 50 years were higher in the case group in comparison with the control group and the mean \pm standard deviation (SD) age of the case and the control groups were $42.5 \pm 12.3$ years and $37.8 \pm 14.6$, years respectively. Over three quarters $(77.1 \%)$ of the case group were male; whereas males constituded $45.7 \%$ of the control group. However, the number of females was higher in the control group (54.3\%) than that in the case group (22.9\%). Educational status describes that about $37 \%$ of the case group was primary level educated, $8.6 \%$ secondary, $12.9 \%$ higher secondary, $4.3 \%$ graduate and $2.9 \%$ was postgraduate. In control group, $15.7 \%$ had education up to primary level, $21.4 \%$ secondary, $27.1 \%$ higher secondary, and $18.6 \%$ graduate. A higher frequency of HBsAg-positivity was found in illiterate patients as compared to HBsAg-negative counterparts ( $34.3 \%$ vs $17.1 \%, p<0.001)$. Occupation-wise, a larger proportion of farmers, retailers, and day-laborer was found in the case group than those in control group; while housewives, service holders, and students were found more in the control group than those in the case group. Besides, the frequency of HBsAg-positivity was found greater in the respondents from the farmers, retailers and daylaborers as compared to HBsAg-negative counterparts (18.6\% vs $5.7 \%$; 34.3 vs 14.3 ; and 7.2 vs $1.4 ; p<0.001)$. The majority (90\%) of the respondents in control group was Muslim, 8.6\% Hindu and the remaining $1.4 \%$ was Christian. Conversely, all of the case group respondents were Muslim. Married participants were equally distributed $(80 \%)$ in the case and the control groups. However, over $14 \%$ of case group was unmarried and $5.7 \%$ widow; whereas $17.1 \%$ of the control group was unmarried and $2.9 \%$ widow. Over $47 \%$ of patients in case group was rural residents, $48.6 \%$ urban and a very few $(4.3 \%)$ was slum residents. On the other hand, $34.3 \%$ of the control group came from rural regions and the rest $65.7 \%$ was from urban areas.

\section{Clinical and Behavior of the Respondents}

Table 2 describing the clinical characteristics of the respondents reveals that all of the variables like jaundice $(75.7 \%$ vs $7.4 \%$, $p<0.001)$, history of sexually transmitted disease $(18.6 \%$ vs $2.9 \%, \mathrm{p}=0.003)$, history of blood transfusion $(18.6 \%$ vs $1.5 \%$, $\mathrm{p}<0.001)$, intra venous drug abuse $(5.7 \%$ vs $1.5 \%, p<0.001)$, and regular consumption of alcohol $(25.7 \%$ vs $1.5 \%, \mathrm{p}<0.001)$ were significantly higher in case group than in the control group.

\section{Assessment of Knowledge of Hepatitis B}

A total of 38 questions were used to assess the knowledge and the awareness of the admitted patients about hepatitis B. Score "1" was given for each correct response and " 0 " for each wrong response. The score obtained for each discrete question were then added together to find an integrated score out of 38 . The total score thus obtained from the respondents' answers was converted into percentage and was subdivided into 5 categories indicating highly dissatisfactory (0-20\%), dissatisfactory (21-40\%), neither satisfactory nor dissatisfactory (41-60\%), satisfactory (61$80 \%$ ), and highly satisfactory (>80\%). As shown in the Table 3 , neither satisfactory nor dissatisfactory as well as satisfactory level of knowledge was noticed to be considerably higher in the case group as compared to the control group $(41.4 \%$ vs $34.3 \%$ and $24.2 \%$ vs $14.3 \%$, respectively). In contrast, highly dissatisfactory and dissatisfactory level of knowledge was found higher in the control group than in the case group $27.2 \%$ vs $14.3 \%$ and $24.2 \%$ vs $20.1 \%$, respectively). However, the association between the groups concerning the level of knowledge and awareness were not statistically significant $(\mathrm{p}=0.494)$.

Again, Tables 4,5,6 illustrate the level of knowledge regarding hepatitis B and mode of transmission, consequences and prevention of HBV infections among the respondents of two different groups. After evaluating the respondents' opinion, it was found that the HBsAg-positive respondents correctly answered more questions (29 questions out of 38) in comparison with the HBsAg-negative patients.

From the Table 4 demonstrating the knowledge about hepatitis $B$ and its mode of transmission, it is found that $75.7 \%$ of the HBsAgpositive respondents realized hepatitis $\mathrm{B}$ as a significant health problem in Bangladesh. $84.3 \%$ and $65.7 \%$ of the interviewees of the case and the control groups respectively identified it as an infectious disease; whereas only $52.9 \%$ and $28.6 \%$ of the respective groups adequately respond that virus was a cause of hepatitis B infection. When the respondents were questioned about the organs affected by HBV infection, respectively $74.3 \%$ and $80 \%$ of the case and the control groups correctly answered as liver, while $25.7 \%$ and $20 \%$ give an incorrect answer. Moreover, regarding mode of transmission of hepatitis B, $50 \%$ and $70 \%$ of the case and control groups respectively mentioned blood and blood products transfusion, $50 \%$ and $62.9 \%$ infected needles, $35.7 \%$ and $27.1 \%$ unsterilized surgical/dental instruments, $21.4 \%$ and $25.7 \%$ "from mother to baby" and only $47.1 \%$ and $52.9 \%$ referred to sexual intercourse.

Table 5 shows the various level of knowledge about the consequences of $\mathrm{HBV}$ infection among the patients of two different groups. From the table, it is clear that the case group had higher level of knowledge about the consequences of hepatitis B infection than the control group: development of cirrhosis $(40 \%$ vs $24.3 \%$, $\mathrm{p}=0.016)$, liver cancer $(48.6 \%$ vs $31.4 \%, p=0.038)$, blood vomiting or black stool $(37.1 \%$ vs $31.4 \%, p=0.476)$, recurrent abdominal and leg swelling $(42.9 \%$ vs $17.1 \%, p=0.001)$, drowsiness or unconsciousness $(31.4 \%$ vs $11.4 \%, p=0.004)$. However, in both groups, a few percentages of the patients were found to have knowledge that HBsAg-positive patients remain carrier. Moreover, the results above indicate the fact that a significant fraction of both groups do not have adequate knowledge about the consequences of the hepatitis B infection. 


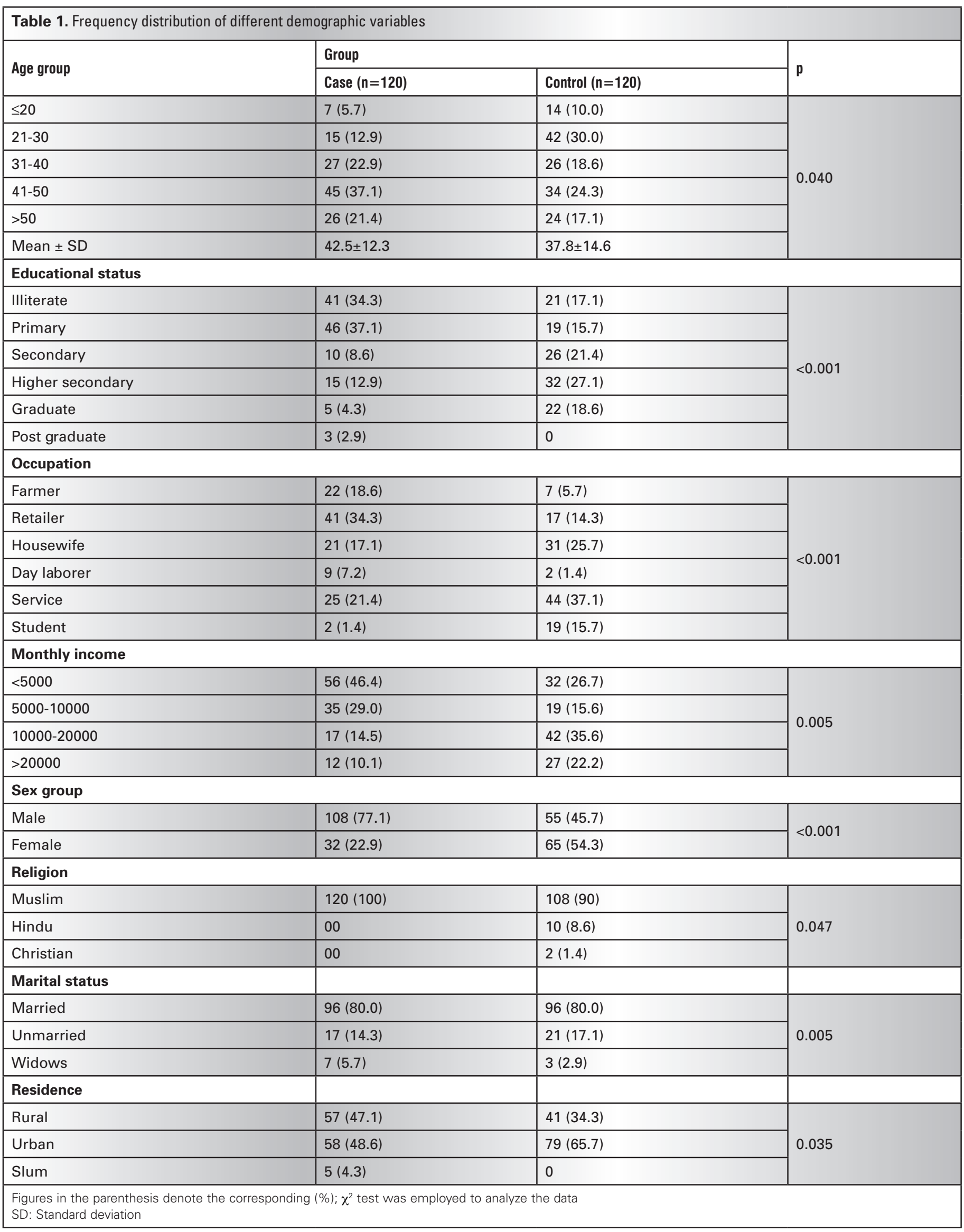


Table 6 displays a various level of knowledge regarding suggestive prevention and treatment of HBV among the patients of two different (case and control) groups. From the table, it is evident that only a small fraction of the patients from both groups knew that treatment for hepatitis B was available. Their level of knowledge about curability of hepatitis $B$ was found to be quite

\begin{tabular}{|l|l|l|l|}
\hline Table 2. Information about clinical and behavior of respondents & \multirow{2}{|l|}{} \\
\hline \multirow{2}{*}{ Information } & \multicolumn{2}{|l|}{ Group } & Control $(\mathbf{n}=120)$ \\
\cline { 2 - 4 } & \multicolumn{1}{l|}{ Case $(\mathbf{n = 1 2 0})$} & $9(7.4)$ & $<0.001$ \\
\hline Jaundice & $91(75.7)$ & $3(2.9)$ & 0.003 \\
\hline History of STD & $22(18.6)$ & $2(1.5)$ & $<0.001$ \\
\hline H/O blood transfusion & $22(18.6)$ & $2(1.5)$ & $<0.001$ \\
\hline Intra venous drug abuse & $7(5.7)$ & $2(1.5)$ & $<0.001$ \\
\hline Alcohol consumption & $31(25.7)$ & \\
\hline $\begin{array}{l}\text { Figures in the parenthesis denote the corresponding }(\%) ; ~ \\
\text { STD: Sexually transmitted disease }\end{array}$ & \\
\hline
\end{tabular}

Table 3. Patients' knowledge and awareness measured on Likert scale between groups

\begin{tabular}{|c|c|c|c|}
\hline \multirow{2}{*}{ Clinical variables } & \multicolumn{2}{|l|}{ Group } & \multirow{2}{*}{ p } \\
\hline & Case $(n=120)$ & Control $(n=120)$ & \\
\hline Highly dissatisfactory ( $\leq 20 \%$ ) & $17(14.3)$ & $33(27.2)$ & \multirow{5}{*}{0.494} \\
\hline Dissatisfactory (21-40\%) & $24(20.1)$ & $29(24.2)$ & \\
\hline Neither satisfactory nor dissatisfactory $(41-60 \%)$ & $50(41.4)$ & $41(34.3)$ & \\
\hline Satisfactory $(61-80 \%)$ & $29(24.2)$ & $17(14.3)$ & \\
\hline Highly satisfactory (>80\%) & 0 & 0 & \\
\hline
\end{tabular}

Figures in the parenthesis denote the corresponding $(\%) ; \chi 2$ test was employed to analyze the data

Table 4. Knowledge about hepatitis $B$ and its mode of transmission

\section{Questions asked to respondents}

\begin{tabular}{|c|c|c|c|c|}
\hline Q1. & Is it a major health problem in Bangladesh? & $91(75.7)$ & $9(7.4)$ & $<0.001$ \\
\hline Q2. & Is hepatitis B infectious? & $101(84.3)$ & $79(65.7)$ & 0.024 \\
\hline Q3. & Does the virus cause hepatitis $B$ ? & $63(52.9)$ & $34(28.6)$ & 0.014 \\
\hline & Liver & 89 (74.3) & $96(80.0)$ & 0.631 \\
\hline & Heart & $26(21.4)$ & $9(7.1)$ & 0.017 \\
\hline Q7. & Is it transmitted from mother to baby? & $26(21.4)$ & $31(25.7)$ & 0.550 \\
\hline Q8. & Is it transmitted from one person to other? & $55(45.7)$ & $79(65.7)$ & 0.017 \\
\hline Q9. & Is it transmitted by sharing food? & $22(18.6)$ & $12(10.0)$ & 0.147 \\
\hline Q10. & Is it transmitted by touching/handshaking? & $19(15.7)$ & $7(5.7)$ & 0.264 \\
\hline Q14. & Is it transmitted through contaminated food? & $36(30.0)$ & $12(10.0)$ & 0.003 \\
\hline Q15. & Is it transmitted through blood and blood products? & $60(50.0)$ & $84(70.0)$ & 0.016 \\
\hline Q16. & Is it transmitted through reuse of infected needles? & $60(50.0)$ & $75(62.9)$ & 0.125 \\
\hline Q17. & Is it transmitted through sexual intercourse? & $57(47.1)$ & $63(52.9)$ & 0.499 \\
\hline Q18. & $\begin{array}{l}\text { Is it transmitted through unsterilized surgical/dental } \\
\text { instruments? }\end{array}$ & $43(35.7)$ & $33(27.1)$ & 0.275 \\
\hline Q19. & Is it transmitted through saliva? & $24(20.0)$ & $21(17.1)$ & 0.664 \\
\hline
\end{tabular}


similar and inadequate ( $20 \%$ vs $10 \%, p=0.098$ ). However, the majority of the patients of both groups knew about the availability of its vaccine. Control group was found to have higher knowledge about the place of getting the vaccine than the case group $(47.1 \%$ vs $65.7 \%, p=0.027)$. More patients from control group than the case group correctly answered that HBV infection could be prevented by avoiding abnormal sexual behavior (45.7\% vs $65.7 \%$, $p=0.017)$. However, opposite scenario was observed when they were asked whether the risk of HBV infection could be avoided by using a condom (30\% vs $17.1 \%, \mathrm{p}=0.073)$ or not.

\section{Assessment of Awareness About Hepatitis B}

As shown in Table 7, awareness of hepatitis B was evaluated by asking seven questions. The result shows that more than two- thirds of the admitted patients from both groups were not aware of transmission mode and hepatitis B vaccination. Compared to case group, more patients from the control group agreed that everyone should ask for blood screening before transfusion $(42.9 \%$ vs $67.1 \%, p=0.004)$, screen the blood if female/male is HB carrier ( $37.1 \%$ vs $52.9 \%, p=0.062$ ) and get vaccinated against hepatitis $B$ (60\% vs $65.7 \%, p=0.484)$. Irrespective of the groups they belong, a small fraction of the respondents thought that HBsAg-positive patients could donate blood. On the other hand, more than $90 \%$ of the patients from each group agreed on the point that infected patients do not need further investigation and treatment to avoid complications of HBV. Interestingly, more than one-fourth of the study participants from both groups responded that unqualified traditional practitioners can cure HBV.

Table 5. Knowledge about consequences of hepatitis B infections

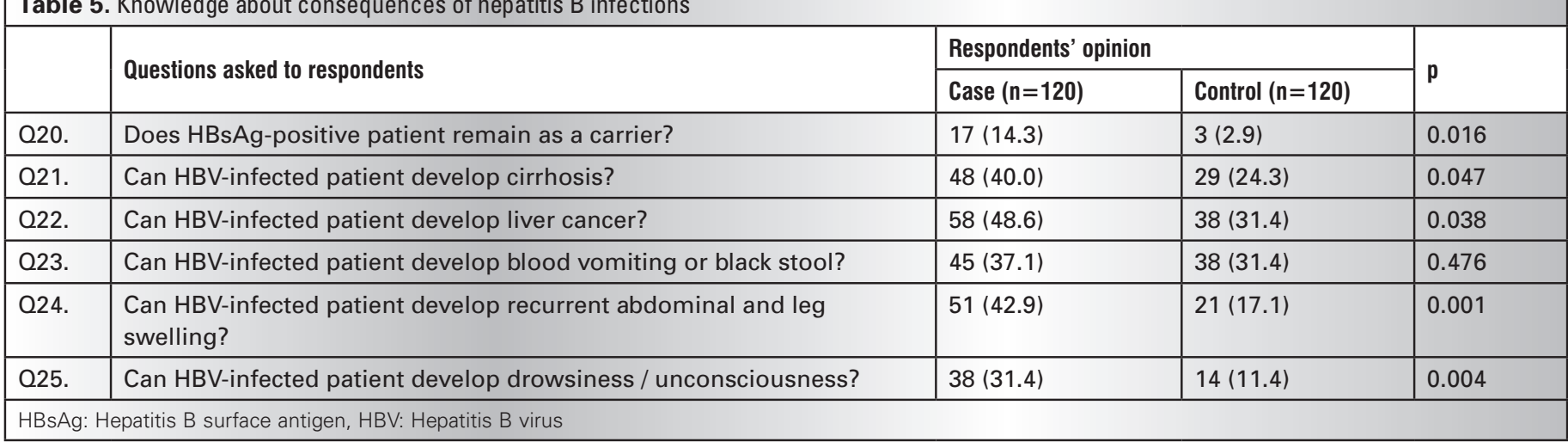

Table 6. Knowledge about prevention of hepatitis B

\begin{tabular}{|c|c|c|c|c|}
\hline & \multirow{2}{*}{ Questions asked to respondents } & \multicolumn{2}{|c|}{ Respondents' opinion } & \multirow{2}{*}{ p } \\
\hline & & Case $(n=120)$ & Control $(n=120)$ & \\
\hline Q26. & Is treatment available? & $24(20.0)$ & $12(10.0)$ & 0.098 \\
\hline Q28. & Do you know where you can get the vaccine? & $57(47.1)$ & $79(65.7)$ & 0.027 \\
\hline Q29. & Is hepatitis B curable? & $24(20.0)$ & $12(10.0)$ & 0.098 \\
\hline Q31. & Does using a condom avoid the risk of hepatitis B & $36(30.0)$ & $21(17.1)$ & 0.073 \\
\hline
\end{tabular}

Table 7. Respondents' awareness about hepatitis B

\begin{tabular}{|l|l|l|l|l|}
\hline Table 7. Respondents' awareness about hepatitis B & \multicolumn{2}{l|}{ Respondents' opinion } & $\mathbf{p}$ \\
\cline { 3 - 5 } & Respondents' agreement with the following statements & Case $(\mathbf{n = 1 2 0})$ & Control (n=120) \\
\hline Q32. & Ask for the screening of blood before transfusion & $51(42.9)$ & $81(67.1)$ & 0.004 \\
\hline Q33. & F/M hepatitis B carriers should screen for hepatitis B & $45(37.1)$ & $63(52.9)$ \\
\hline Q34. & $\begin{array}{l}\text { HBV-infected patients should go for further investigation and } \\
\text { treatment to prevent complications of HBV }\end{array}$ & $12(10.0)$ & $9(7.1)$ & 0.062 \\
\hline Q35. & Everyone should get vaccinated against hepatitis B & $72(60.0)$ & $79(65.7)$ & 0.546 \\
\hline Q36. & HBsAg-positive patients need vaccination & $17(14.3)$ & $7(5.7)$ \\
\hline Q37. & HBsAg-positive patients can donate blood & $7(5.7)$ & $3(2.9)$ \\
\hline Q38. & Unqualified traditional practitioners can cure HBV & $29(24.3)$ & $38(31.4)$ \\
\hline F: Female, M: Male, HBV: Hepatitis B virus, HBsAg: Hepatitis B surface antigen & & 0.484 \\
\hline
\end{tabular}




\section{Discussion}

In this study, the frequency of HBsAg-positivity was found to be higher in illiterate patients compared to HBsAg-negative counterpart indicating the fact that awareness of mode of transmission was related to education level and needs to be built in a less educated segment of the society. Farmers, retailers and day laborers are more commonly affected by HBV infection as compared to HBsAgnegative patients. It shows that hepatitis $B$ has an impact on the patients belonging to a diversity of business from low to high income. Moreover, nearly half (46.4\%) of HBsAg-positive patients are from the lowest income-segment under consideration. These results were similar to that previously reported $(19,20,21)$. The higher prevalence of HBV infection can, therefore, be attributable to the lack of education, poverty and low socio-economic status of the individuals.

Among the hepatitis B affected patients, the prevalence of HBsAg-positivity was found to be higher in urban-based population $(48.6 \%)$ than the rural-based population and significantly higher among males $(77.1 \%)$ than females which is quite similar to the results reported by Lingao et al. (22). This prevalence of HBsAgpositivity is because the urban male population is more exposed to the HBsAg risk factors probably due to their inherently more active lifestyle or behavior. Besides, it is observed from the study that the prevalence of HBsAg was significantly higher among married $(80 \%)$ than single patients. However, Comia et al. (23) in their study showed no significant difference between infected married and single cases. Although with no clear evidence at hand, it is possible that these infected married individuals may have multiple risk factors for infection.

HBV infection, an emerging global health problem, is a common infection in Bangladesh. This study shows that knowledge and awareness of hepatitis B infection and its consequences among patients admitted to SSMCH are variable. Majority mentioned that hepatitis B was an infectious disease caused by a virus and could affect the liver. Respondents, on the other hand, were found to have imperfect knowledge about the specific consequences of this disease and its preventive measures, i.e., their overall level of knowledge and awareness about hepatitis B was not satisfactory (level of dissatisfaction was found to be $51.4 \%$ ). Perhaps, this is because the majority of our respondents were least educated and from low-income group. Thus, the knowledge and the awareness need to be strengthened more in the least educated and lowincome segments of the society.

This study also discovers gaps in public knowledge about the mode of transmission of HBV. Specifically, less than a half of the HBsAg-positive patients recognized that sexual contact $(47.1 \%)$. Sharing a razor (40\%). using unsterilized surgical/dental equipment $(35.7 \%)$, sharing food $(18.6 \%)$, and sharing utensils could spread the virus. Half $(50 \%)$ of them identified "unsafe blood and blood product transfusion" and reuse of injected needles as major causal factors. Besides, $21.4 \%$ and $45.7 \%$ of respondents of this group thought that hepatitis B could spread from "mother to baby through childbirth" and "one person to another" respectively. However, about one-third (30\%) of the respondents mixed up hepatitis A with hepatitis $B$, and mistakenly mentioned that eating contaminated food was a mode of transmission for hepatitis B. Despite knowing the availability of vaccine, only one-fifth of the respondents believed that hepatitis B was treatable and curable. The similar results are also found in previous studies $(24,25,26)$ conducted by various research groups.

From the above discussion, it is apparent that though the majority of the patients admitted to this hospital had an idea about the cause of HBV infection, they had substantial misunderstandings about its mode of transmission and consequences. Moreover, they took its preventive measures too lightly. These observations were found quite similar to those of Choe et al. (27).

\section{Conclusion}

Admitted patients (both HBV infected and non-infected) from least educated and a low-income segment of the society and the urban male populations were more exposed to the HBsAg risk factors. They were found to have an inadequate overall level of knowledge and awareness about HBV infection and its consequences. They had a considerable misapprehension about its mode of transmission. Therefore, large-scale studies are needed to formulate a plan for educating the patients regarding the mode of transmission and the fate of HBV infection. The knowledge gap derived from this study is to be addressed adequately through proper health education to create awareness and hence, prevent $\mathrm{HBV}$ infection. An effective health promotion program encouraging the urban male population to change their risky behaviors need to be developed and implemented, and specifically-targeted hepatitis $B$ awareness-raising campaigns need to be launched for general as well as high-risk populations at healthcare setting and community level.

\section{Ethics}

Ethics Committee Approval: This study has been approved by an ethical review committee of the Sir Salimullah Medical College and Mitford Hospital, Dhaka, Bangladesh (approval number: ECMD/2016/17).

Informed Consent: Respondents were selected randomly and were included only after obtaining verbal informed consent.

Peer-review: Externally and internally peer-reviewed.

\section{Authorship Contributions}

Design: N.Z., U.S., Data Collection or Processing: N.Z., M.A.S.S., T.M., Analysis or Interpretation: N.Z., Literature Search: M.A.A., Md.M.R., Writing: N.Z.

Conflict of Interest: The authors claim that they have no conflict of interest.

Financial Disclosure: The authors declared that this study received no financial support.

\section{References}

1. World Health Organization (WHO). Prevention and control of viral hepatitis: Frame work for global action, 2012, Available from: http://www.who.int/csr/disease/hepatitis/GHP_Framework_En. Pdf and accessed on June 26, 2013.

2. Centers for disease control and prevention (CDC). World Hepatitis Day-July $28^{\text {th }}$. Available from: http://www.cdc.gov/features/ds hepatitis awareness/index.html and accessed on 2011 June 26, 2013.

3. Lavanchy D. Hepatitis B virus epidemiology, disease burden, treatment, and current and emerging prevention and control measures. J Viral Hepat. 2004;11:97-107. 
4. Dienstag JL. Hepatitis B Virus Infection. N Engl J Med 2008:359:1486-1500.

5. Alam S, Azam G, Mustafa G, Alam M, Ahmad N. Past, Present, and Future of hepatitis B and fatty liver in Bangladesh. Gastroenterol Hepatol Open Access. 2017;6:00197.

6. Khan M, Dong JJ, Acharya S, Dhagwahdorj Y, Abbas Z, Jafri W, Mulyono DH, Tozun N, Sarin SK. Hepatology issues in Asia: Perspectives from regional leaders. J Gastroenterol Hepatol. 2004;19:419-430.

7. Gentile I, Borgia G. Vertical transmission of hepatitis B virus: challenges and solutions. International Journal of Women's Health. 2014;6:605-611.

8. Doganci T, Uysal G, Kir T, Bakirtas A, Kuyucu N, Doganci L. Horizontal transmission of hepatitis $B$ virus in children with chronic hepatitis B. World J Gastroenterol. 2005;11:418-420.

9. Sabin KM, Rahman M, Hawkes S, Ahsan K, Begum L, Black RE, Baqui $\mathrm{AH}$. Sexually transmitted infections prevalence rates in slum communities of Dhaka, Bangladesh. Int J STD AIDS. 2003;14:614621.

10. Hawkes S. Commentary: Human immunodeficiency virus and hepatitis in Bangladesh: widespread or targeted prevention strategies Int J Epidemiol. 2001;30:885-886.

11. Ahad MA, Alim MA. Current Challenges in hepatitis B. TAJ. 2006;19:38-44.

12. Medinews, Vol-1, No-3, September 2005

13. Sayeed MA, Ahmed S, Siraji D, Hoque MG. Knowledge and status of Hepatitis B vaccination among the newly admitted MBBS students in Chittagong Medical College. JCMCTA. 2007;18:9-11.

14. Ahmed MS, Chowdhury OA, Khatoon M, Kabir F, Chowdhury AR, Jahan $\mathrm{H}$, Shamsher M, Assistant A. Seroprevalence of hepatitis virus antibodies in newly admitted students of sylhet MAG Osmani Medical College. Bangladesh J Med Microbiol. 2009;3:2026

15. Uddin KR, Akter S, Jinnah CK, Talukder AA. Epidemiological study of active hepatitis B and C viruses' infection among patients attended in tertiary care hospital in Dhaka City, Bangladesh. Journal of Applied Pharmaceutical Science. 2014;4:102-109.
16. Uddin Al, Pervin M, Munna MS, Noor R. Study of risk factors related to HBsAg reactivity among outdoor patients in Dhaka Medical College and Hospital, Bangladesh. Am J Biomed Life Sci. 2014;2:18-21.

17. Jobayer M, Afroz Z, Rahman M, Akter N, Shamsuzzaman SM, Islam KMS. Hepatitis: knowledge and awareness among the infected population. Bangladesh Med Res Counc Bull. 2017;43:126-130.

18. Taylor GJ, Ryan D, Bagby RM. Toward the development of a new self-report alexithymia scale. Psychother Psychosom. 1985:44:191-199.

19. Khattak AK, Ullah A, Javed M, Ullah R, Hassan MK, Jadoon Z, Hameed K, Khan IM, Khan AG. To find out the frequency of hepatitis B surface antigen positivity in motivated people of Jamrud Tehsil Khyber Agency. JPMI. 2009;93:213-217.

20. Taylor VM, Yasui Y, Burke N, Choe JH, Acorda E, Jackson JC. Hepatitis B knowledge and testing among vietnamese-american women. Ethn Dis. 2005;15:761-767.

21. Wasley A, Alter MJ. Epidemiology of hepatitis C: geographic differences and temporal trends. Semin Liv Dis. 2000;20:1-16.

22. Lingao $A L$, Domingo EO, West $S$, Reyes $C M$, Gasmen $S$, Viterbo G, Tiu E, Lansang MA. Seroepidemiology of hepatitis B virus in the Philippines. Am J Epidemiol. 1986;123:473-480.

23. Comia LL, Manalastas R, Cruz F. Prevalence of hepatitis B infection in pregnant patients using radioimmunoassay. Phil $\mathrm{J}$ Microbiol Infect Dis. 1999;28:53-58.

24. Khokhar N, Gill ML, Yawar A. Interspousal transmission of hepatitis C virus. J Coll Physicians Surg Pak. 2005;15:587-589.

25. Younus $M$, Khan BS. Comparison of risk factors for hepatitis $B$ and $\mathrm{C}$ in patients visiting a gastroenterology clinic. J Coll Physicians Surg Pak. 2006;16:739-740.

26. Taylor VM, Jaackson JC, Chan N, Kuniyuki A, Yasui Y. Hepatitis B knowledge and practices among Cambodian American women in Seattle, Washington. J Community Health. 2002;27:151-163.

27. Choe JH, Chan N, Do HH, Woodall E, Lim E, Taylor VM. Hepatitis $B$ and liver cancer beliefs among Korean immigrants in Western Washington. Cancer. 2005;104:2955-8. 